\title{
Vzájomná podmienenost' kondičných a koordinačných schopností 13- až 14-ročných atlétov
}

\section{Interdependence conditionality of condition and coordination skills 13- to 14 year athletes}

\author{
Ladislava Doležajová, Erik Stenchlák
}

Fakulta telesnej výchovy a športu University Komenského, Bratislava, Slovensko

\begin{abstract}
Abstrakt
Ciel’om výskumu bolo zistit' vzájomnú podmienenost' kondičných a koordinačných schopností 13- až 14ročných atlétov. Otestovali sme vybrané kondičné a koordinačné schopnosti. Na základe korelačnej matice sme zist'ovali vzájomnú podmienenost' medzi vekom, telesnými ukazovatelmi a testami pohybových schopností. Konštatujeme, že sme nezistili vyšši počet pozitívnych súvislostí medzi ukazovatel’mi veku, telesného rozvoja $k$ testom kondičných schopností. Potvrdili sme, že koordinačné schopnosti sú menej ovplyvnené telesným rozvojom ako kondičné schopnosti. Korelačná matica potvrdila faktorové sýtenie a to najmä v testoch s komplexnejšimi požiadavkami na úroveň pohybových schopností.
\end{abstract}

\begin{abstract}
The purpose of study was to find interdependence conditionality of condition and coordination skills of 13 up to 14 year old athletes. We analyzed condition and coordination skills of athletes and based on the correlation matrix, we investigated the interdependence conditionality between age, anthropometry and analyzed movement skills. We do not found any statistically significant positive link between indicators of age, physical development to tests the condition skills. We confirmed that coordination skills are less affected by physical development. Correlation matrix confirmed the factor saturation in different parameters, especially in tests with more complex requirements on the level of movement skills.
\end{abstract}

Kl'účové slová: atletika, kondičné schopnosti, koordinačné schopnosti, športová príprava, 13-až 14-roční atléti

Key words: track and field, conditioning abilities, coordination skills, sports preparation, 13- to 14-year-old athletes

ÚVOD

Atletika patrí medzi základné športové odvetvia s komplexným účinkom na organizmus človeka. Prostriedkami atletiky rozvíjame základné pohybové schopnosti - kondičné a koordinačné, ako aj funkčné schopnosti organizmu. Zručnosti a schopnosti získané atletikou nachádzajú vel'ké uplatnenie v iných športových odvetviach (Čillík a Rošková 2003).

V súčasnom období je možnost' rozvíjat' a zdokonal'ovat' svoj atletický potenciál v športových triedach. Športové triedy sú určené na systematickú športovú prípravu športovo-talentovaných žiakov. Činnost' v nich je zameraná na optimálny rozvoj pohybových predpokladov žiakov na konkrétne športové odvetvie. Obsahom špeciálnej kondičnej prípravy sú špecifické cvičenia, ktoré sú zamerané na rozvoj kondičných a koordinačných pohybových schopností (Čillík, 2003). V každej pohybovej činnosti podla Šimoneka (2012) možno pozorovat' prejavy rýchlosti, sily, vytrvalosti, koordinácie atd'. Ich pomer je v konkrétnych prípadoch rôzny, závisí pritom od pohybovej úlohy, ktorá sa práve plní. Israel (1977) a Šimonek (2002) konštatujú, že koordinačné schopnosti sú diferencovane prepojené s komplexom kondičných schopností a tvoria najmenej prebádanú skupinu motorických schopností. Ljach - Mynarski a Raczek (1995) pritom zdôrazňujú ich úzku väzbu koordinačných schopností na psychofyzické vlastnosti človeka. Problematikou vzt’ahov kondičných a koordinačných schopností sa zaoberali 
aj autori Kordoš (2007), Hegedüšová (2007), ktorí sledovali vzájomnú podmienenost' na vzorke 10- až 11-ročných resp. 10- až 12-ročných atlétov a atlétok a preukázali vzájomnú podmienenost' medzi ukazovatel'mi veku, telesného rozvoja s testami kondičných schopností a menej s koordinačnými schopnost’ami. Zapletalová (1990) vo veku 10- až 14-rokov zaznamenala zvýšenie tesnosti telesného rozvoja a pohybovej (kondičnej) výkonnosti, pričom za najtesnejšie označila vzt’ahy v kategórii 13- až 14- ročných chlapcov a dievčat od 13 do 15 rokov. Podl'a Hantoushiho (2000) tesnejšie súvislosti medzi motorickým výkonom a telesným rozvojom sa evidujú u mládeže, ako u dospelých, osobitne v pubertálnom veku. U športujúcich detí a mládeže vyššie súvislosti, ako u normálnej populácie, viac poukazujú na vyšší stupeň utilizácie telesného rozvoja (hlavne telesnej výšky a hmotnosti) v športovej technike. Autori Ljach, Mynarski a Raczek (1995) konštatujú, že úroveň kondičných schopností je podmienená predovšetkým rozvojom rýchlostných a rýchlostno-silových schopností. Sedláček (1996) sleduje zvýšené hodnoty koeficientov medzi testami beh na $50 \mathrm{~m}$ a beh 10x5 m. Autori Koštial, Lednický a Doležajová (2006) hovoria o nezávislosti prejavov koordinačných schopností na telesný rozvoj športovcov. Tento názorom potvrdzuje aj Kampmiller (1996), ktorý konštatuje, že najmenej ovplyvnené telesným rozvojom sú koordinačné schopnosti, najviac silové, rýchlostno-silové, vytrvalostné a rýchlostné. Israel (1977) nachádza súvislosti vo vytrvalostnom behu k testom koordinačných schopností, Hegedüšová (2007) na vzorke 10- až 12- ročných atlétkach vzt’ah nepotvrdila. Doležajová (2002) konštatuje, že kinesteticko-diferenciačná schopnost' vystupuje bez priameho súvisu s telesnými ukazovatel'mi a kondičnými testami. Poznatky zo vzt’ahových analýz medzi športovým výkonom, resp. výkonnost'ou v motorických testoch a telesným rozvojom sa vyznačujú osobitost’ami v závislosti od športových disciplín, veku, úrovne výkonnosti a sexuálneho dimorfizmu (Havlíček, 1990).

Z týchto dôvodov sme sa zamerali na zistenie vzájomnej podmienenosti medzi ukazovatel'mi veku, telesného rozvoja, vybranými kondičnými a koordinačnými schopnost’ami na súbore 13- až 14- ročných atlétoch a atlétkach.

\section{CIEL' VÝSKUMU}

Ciel'om práce je objasnit' vzájomnú podmienenost' a vysvetlit' vzt'ahy medzi jednotlivými skupinami pohybových schopností na vzorke 13- až 14-ročných atlétov športových tried.

\section{HYPOTÉZY VÝSKUMU}

H.1: Predpokladáme úzky vzt’ah ukazovatel'ov veku a telesných ukazovatel'ov $\mathrm{k}$ testom kondičných schopností v súbore chlapcov aj dievčat, potvrdíme nezávislost' týchto ukazovatel'ov od testov koordinačných schopností.

H.2: Predpokladáme vzájomnú podmienenost' medzi testami, ktoré sú sýtené viacerými pohybovými schopnost'ami.

\section{METODIKA VÝSKUMU}

\section{Charakteristika súboru}

Sledované súbory tvorilo19 atlétov a 14 atlétok vo veku 13- až 14- rokov. Atléti boli žiakmi športových tried v Bratislave a Malackách so zameraním na atletiku. Do športových tried boli vybratí na základe výberu z talentových skúšok. Všeobecnej športovej príprave sa začali venovat’ od piateho ročníka.

U všetkých atlétov sme zist'ovali základné telesné ukazovatele a výkony v šiestich kondičných a piatich koordinačných testov. Meranie sme uskutočnili začiatkom školského roka 2012/2013. Medián veku atlétov bol 13,82 s variačným rozpätím $(13,02-14,68)$ a dievčat 13,33 roka, s variačným rozpätím $(13,07$ - 13,93). Medián telesnej výšky chlapcov bol 163,0 a dievčat $163,3 \mathrm{~cm}$ a telesnej hmotnosti 53,0 resp. 48, $5 \mathrm{~kg}$.

\section{Metódy získavania údajov}

Pri získavaní výskumných údajov sme použili metódy merania podl’a Sedláčeka a Cihovej (2009). Na zistenie všeobecného pohybového rozvoja atlétov sme zvolili všeobecné testy kondičného a koordinačného charakteru podl'a Šimoneka (2012). 


\section{Sledované ukazovatele}

DV - decimálny vek, TV - telesná výška, TH - telesná hmotnost’, BMI - hmotnostno-výškový index, ), 50 m - beh na 50 m (rýchlostné schopnosti), 12 min - 12 minútový beh (vytrvalostné schopnosti), SDDM - skok do dial'ky z miesta znožmo (výbušná sila dolných končatín), HPL - hod plnou loptou (výbušná sila horných končatín), OHB - predklon v stoji (ohybnost'), SL' - sed-l'ah za $30 \mathrm{~s}$ (sila brušných svalov a ohýbačov stehna), 10 x 5 m - člnkový beh (rýchlostno-koordinačný beh), LAVOBR - prebeh po lavičke s troma obratmi o $360^{\circ}$ (rovnováhová schopnost'), LAVLOP - zastavenie kotúl'ajúcej sa lopty (komplexný reakčný test), BEHM - beh k métam (priestorovo-orientačný beh), SDDP - skok do dial'ky z miesta na presnost' (kinesteticko-diferenciačná schopnost' dolných končatín).

\section{Metódy spracovania a vyhodnocovania údajov}

Súvislosti medzi všetkými sledovanými ukazovatel'mi objasňujeme s využitím párovej korelačnej analýzy podl'a Persona. Štatistickú významnost' posudzujeme na 1\% a 5\% hladine štatistickej pravdepodobnosti. Korelačnú maticu atlétov a atlétok uvádzame v Tabul'ke 1 a Tabul'ke 2.

\section{VÝSLEDKY A DISKUSIA}

V súbore chlapcov vzt’ah DV k telesným ukazovatel'om sa nám v korelačnej matici neprejavil. Vzt’ah DV $\mathrm{s}$ testom SDDM a behom 10x5 m sme zistili na 1\% hladine významnosti. Na $5 \%$ hladine sledujeme vzt'ah medzi DV a behom na 12 min. Vo vzt'ahu k TV pozorujeme len 3 kondičné testy a to SDDM na 1\% hladine, na 5\% hladine HPL a 12 min. beh. Vzt’ah TH k testom sme nezaznamenali. BMI preukázal vzt’ah iba s testom koordinačných schopností LAVOBR na 5\% hladine významnosti.

Vsúbore dievčatpodobneakou chlapcovvzt'ahDVktelesnýmukazovatel'om sa neprejavil. Nezaznamenávame vzt'ah ani DV k testom kondičného a koordinačného charakteru. Vo vzt'ahu k TV sme zaznamenali na 5\% hladine významnosti test SDDM a $12 \mathrm{~min}$. beh. Sledujeme závislost' BMI k trom kondičným testom SDDM, beh $50 \mathrm{~m}$ a $12 \mathrm{~min}$. beh na 5\% hladine významnosti. BMI preukázal vzt’ah s jedným koordinačným testom LAVLOP a to na $1 \%$ hladine významnosti. Sme prekvapení, že sa nám nepodarilo potvrdit' prvú čast' H 1 , kde sme predpokladali úzky vzt'ah medzi ukazovatel'om veku, telesného rozvoja s testami kondičných schopností. Ani v jednom sledovanom súbore sme nezistili vyšší počet signifikantných súvislostí a naše výsledky sa nestotožňujú s výskumy Zapletalovej (1990), Kampmillera (1996) a Hantoushiho (2000). Títo autori sa zhodujú, že práve naše sledované vekové obdobie u chlapcov a dievčat vykazuje zo všetkých vekových období najviacej tesnosti medzi telesnými ukazovatel'mi a výkonnost'ou v kondičných testoch. V druhej časti H1 sa nám hypotéza potvrdila a konštatujeme ako už uvedení autori, že koordinačné schopnosti sú relatívne menej ovplyvnené telesným rozvojom a na našom súbore atlétov a atlétok sa tento argument potvrdil.

$\mathrm{V}$ testoch kondičného charakteru u chlapcov zist'ujeme viaceré súvislosti. Tesnejšia prepojenost' sa objavila medzi kondičnými testami navzájom, kde z 21 skúmaných vzt'ahov sme potvrdili tesnost' 13 z nich. Potvrdzujeme faktorové sýtenie testu SDDM, kde korelačné súvislosti poukazujú na vzájomnú podmienenost' rýchlostných, rýchlostno-silových a vytrvalostných schopností $\mathrm{k}$ testom beh $10 \times 5 \mathrm{~m}, \mathrm{HPL}, 50 \mathrm{~m}$ beh, 12 min. beh a BEHM a to na $1 \%$ hladine štatistickej významností. 5\% štatistickú významnost' sledujeme medzi SDDM s LAVLOP. Na 1\% hladine štatistickej významnosti potvrdzujeme vzt'ah testu beh $10 \times 5 \mathrm{~m}$ k testom HPL s $12 \mathrm{~min}$. beh a $5 \%$ hladina potvrdila významnost' testu beh 10x5 m k trom testom beh $50 \mathrm{~m}$, LAVLOP a BEHM. Väčší počet korelačných súvislostí sa vyskytuje na $1 \%$ hladine štatistickej významností aj medzi testom HPL, ktorý koreloval s OHB, beh $50 \mathrm{~m}$, BEHM, SDDM a beh 10x5 m. Na 5\% hladine štatistickej významnosti sme potvrdili vzt'ah testu HPL s beh 12 min., SDDP, LAVLOP. V teste SL nezaznamenávame žiadnu súvislost' s kondičnými a koordinačnými testami. $\mathrm{V}$ teste OHB sledujeme faktorové sýtenie k testom HPL, beh $50 \mathrm{~m}$, beh 12 min. na 5\% hladine významností. Vzt'ah OHB s BEHM zaznamenávame na $1 \%$ hladine. V teste beh na 50 m sme zaznamenali 5\% štatistickú významnost' s BEHM, LAVLOP, OHB a beh 10x5 m. Na 1\% hladine tento test súvisel s SDDM, beh $12 \mathrm{~min}$. a HPL. Beh na 12 min. nám úzko súvisel na $1 \%$ hladine s testami BEHM, SDDM, beh $50 \mathrm{~m}$ a beh $10 \times 5 \mathrm{~m}$.

V testoch koordinačných schopností zaznamenávame menší počet významných súvislostí v teste SDDP s HPL sme zaznamenali štatistickú významnost' na 5\% hladine. LAVOBR nezaznamenávame koreláciu so žiadnym testom. Väčší počet korelačných súvislostí sa vyskytuje aj v teste LAVLOP k piatim kondičným testom (SDDM, 10x5 m, HPL, beh $50 \mathrm{~m}, 12 \mathrm{~min}$. beh) a to na 5\% hladine významnosti. Významné faktorové sýtenie sledujeme v teste BEHM k testom SDDM, HPL, OHB, 12 min. beh na 1\% hladine. Na 5\% hladine koreloval s LAVLOP, 10x5 m a $50 \mathrm{~m}$. 
V súbore dievčat $\mathrm{v}$ porovnaní $\mathrm{s}$ chlapcami sledujeme menšiu prepojenost' medzi kondičnými testami navzájom, kde z 21 skúmaných vzt'ahov sme potvrdili tesnost' 8 z nich. Jednou z príčin môže byt' aj rozdielne variačné rozpätie telesných ukazovatel'ov. U chlapcov sme zistili variačné rozpätie v TV $19 \mathrm{~cm}$ a TH $15 \mathrm{~kg}$ a dievčat v TV len $15 \mathrm{~cm}$, ale až $30 \mathrm{~kg}$ v TV. V korelačnej matici sme zistili faktorové sýtenie a prepojenie testu SDDM k testom 10x5 m, OHB a BEHM na 5\% hladine významnosti. Súvislost' na 1\% hladine potvrdzujeme medzi SDDM k testom beh $50 \mathrm{~m}, 12 \mathrm{~min}$. beh, LAVLOP a LAVOBR. Na 5\% hladine pravdepodobnosti sme zistili štatisticky významné súvislosti medzi testami 10x5 m s SDDM, OHB a LAVLOP. V teste HPL a SL nezaznamenávame korelačnú súvislost' $\mathrm{k}$ iným testom. Tesnejšiu prepojenost' zaznamenávame v teste OHB k SDDM, beh 10x5 m, 50m a BEHM na 5\% hladine významnosti. 1\% hladinu štatistickej významnosti sme zaznamenali k beh 12 min. a LAVOBR. V behu na $50 \mathrm{~m}$ na $1 \%$ hladine významnosti sledujeme vzt’ah k SDDM, LAVLOP a LAVOBR.

V koordinačnej oblasti sa tesnejší potvrdil vzt’ah na $5 \%$ hladine štatistickej významnosti v teste BEHM a testom SDDM, OHB a 12 min. beh. Spomedzi koordinačných testov najväčšie faktorové sýtenie sledujeme medzi testami LAVOBR s SDDM, OHB, $12 \mathrm{~min}$. a beh $50 \mathrm{~m}$ na $1 \%$ hladine. V teste SDDP nezaznamenávame žiadnu závislost' k ostatným testom a opät' potvrdzujeme, že kinesteticko-diferenciačná schopnost' vystupuje bez priamej súvislosti k testom kondičného charakteru.

Výsledky korelačnej analýzy dokazujú, že existuje diferencovaná, vzájomná podmienenost' medzi kondičnými a koordinačnými schopnost’ami v súbore chlapcov a dievčat. Stotožňujeme sa s autormi Ljachem, Mynarskim a Raczekom (1995), že úroveň kondičných schopností je podmienená predovšetkým rozvojom rýchlostných a rýchlostno-silových schopností. Potvrdzujeme aj tézu Izraela (1977), kde autor konštatuje vplyv aeróbnej vytrvalosti na úroveň koordinačných schopností. Podl’a našich zistení v súbore atlétov, ale aj atlétok beh na 12 min. koreloval s tromi zo štyroch koordinačných testov (BEHM, LAVLOP a LAVOBR). Konštatujeme, že sme potvrdili H2, kde sme predpokladali vzájomnú podmienenost' medzi testami, ktoré sú sýtené viacerými pohybovými schopnost’ami.

\section{ZÁVERY}

Ciel'om príspevku bolo zistit' vzájomnú podmienenost' medzi vekom, telesnými ukazovatel'mi, kondičnými a koordinačnými schopnost’ami 13- až 14-ročných atlétov a atlétok, žiakov športových tried.

1. V hypotéze1 (H1) sme predpokladali úzky vzt'ah ukazovatel'ov veku, telesných ukazovatel'ov k testom kondičných schopností aj $\mathrm{v}$ súbore chlapcov a dievčat, potvrdíme nezávislost' týchto ukazovatel'ov od testov koordinačných schopností. Konštatujeme, že sme nezistili väčší počet pozitívnych súvislostí medzi ukazovatel'mi veku, telesného rozvoja k testom kondičných schopností, prvá čast' hypotézy 1 nepotvrdená. Z výsledkov d’alej vyplýva, že sme dokázali na našich súboroch, že koordinačné schopnosti sú relatívne menej ovplyvnené telesným rozvojom a náš výskum potvrdil práce autorov, ktorí sa touto problematikou zaoberali už v minulosti na rôznych vzorkách populácie alebo športujúcej mládeže.

2. V hypotéze 2 (H2) sme predpokladali vzájomnú podmienenost' medzi testami, ktoré sú sýtené viacerými pohybovými schopnost’ami. Korelačná matica potvrdila faktorové sýtenie a to najmä v testoch s komplexnejšími požiadavkami na úroveň pohybových schopností. Odporúčame preto uprednostňovat' v športovej príprave podnety s komplexnejším pôsobením na viacero pohybových schopností kondičného a koordinačného charakteru.

3. Naše výsledky v porovnaní s citovanými autormi nepotvrdili vždy ich zistenia. Môže to byt' zapríčinené viacerými faktormi, medzi ktoré $\mathrm{z}$ nášho pohl’adu patria: homogenita súboru tj. variačné rozpätie veku a telesných ukazovatel'ov skúmaných súboroch, rôzny biologický vek jednotlivcov, doba športového veku, objektívnost' nameraných predchádzajúcich údajov apod. Z týchto dôvodov budú potrebné d’alšie výskumné sledovania.

4. Potvrdili sme nezávislost' kinesteticko-diferenciačnej schopnosti od kondičných schopností. V praxi to znamená, že táto koordinačná schopnost' je viazaná na procesy riadenia a regulácie CNS. Z toho vyplýva, že v športovej príprave už v tejto vekovej kategórii sa musia využívat' cvičenia s dôrazom na presnost' vykonania, ktoré sú omnoho náročnejšie, pretože vyžadujú koncentráciu pozornosti a motiváciu k ich realizácii.

5. Uvedomujeme si, že naše výsledky prezentujeme na malej vzorke atlétov a atlétok, takže uvedené výsledky platia pre túto sledovanú skupinu a nedajú sa zovšeobecňovat'. 


\section{LITERATÚRA}

Čillík, I. (2003). Učebné osnovy športovej prípravy v atletike. Nové Zámky: CROCUS.

Čillík, I., \& Rošková, M. (2003). Základy atletiky. Banská Bystrica: Univerzita Mateja Bela.

Doležajová, L. (2002). Úroveň a vzájomná podmienenost' kondičných a koordinačných schopností žiačok ZŠ.

In Acta Fac. Educ. Phys. Univ. Comenianae. 43, 2002,11-17. Bratislava: Fakulta telesnej výchovy a športu, Univerzita Komenského.

Hantoushi, L. A. (2000). Závislost' atletickej výkonnosti od telesného rozvoja a pohybových schopností. Dizertačná práca. Bratislava: Fakulta telesnej výchovy a športu, Univerzita Komenského.

Havlíček, I. (1990). Vývinová stabilita a predikční validita telesného rozvoja a motorickej výkonnosti. In Acta Fac. Educ. Phys. Univ. Comenianae. 29, 1990, 147-218. Bratislava: Slovenské pedagogické nakladatel'stvo.

Hegedüšová, A. (2007). Vzájomná podmienenost' kondičných a koordinačných schopností 10- až 12-ročných atlétok. Diplomová práca. Bratislava: Fakulta telesnej výchovy a športu Univerzity Komenského.

Israel, S. (1977). Rechtzeitige Entwicklung der Bewegungskoordination. Leichtathletik, 28, (5), 989-992.

Kampmiller, T. (1996). Závislost' pohybovej výkonnosti od telesného rozvoja. In Moravec, R., Kampmiller, T. \& Sedláček, J. et al. (1996). Eurofit. Telesný rozvoj a pohybová výkonnost’ školskej populácie na Slovensku (112-120). Bratislava: Slovenská vedecká spoločnost' pre telesnú výchovu a šport.

Kordoš, L. (2007). Vzájomná podmienenost’ kondičných a koordinačných schopností 10- až 11- ročných atlétov športovej triedy a športového gymnázia. Diplomová práca. Bratislava: Fakulta telesnej výchovy a športu Univerzity Komenského.

Ljach, V. I., Mynarski, W. \& Raczek. J. (1995). Biopsychiczne predyspozycje koordynacyjnych zdolnosci motorycznych - przeglad badaň w pismiennictwie rosyjskojezycznym. Antropomotoryka, 12. 83-102.

Sedláček, J. (1996). Tesnost' vzt’ahov medzi motorickými testmi zaradenými do našich zostáv a do Eurofitu. In Moravec, R., Kampmiller, T., Sedláček, J. a kol.: Eurofit. Telesný rozvoj a pohybová výkonnost’ školskej populácie na Slovensku (122-127) Bratislava: Slovenská vedecká spoločnost’ pre telesnú výchovu a šport.

Sedláček, J., \& Cihová, I. (2009). Športová metrológia. Bratislava: ICM AGENCY. Šimonek, J. (2002). Model rozvoja koordinačných schopností v dlhodobej športovej príprave v športových hrách. Bratislava: Slovenská vedecká spoločnost’ pre telesnú výchovu a šport.

Šimonek, J. (2012). Testy pohybových schopností. Nitra: Dominant Nitra.

Zapletalová, L. (1990). Závislost' pohybovej výkonnosti od telesného rozvoja. In Moravec, R. a kol. Telesný, funkčný rozvoj a pohybová výkonnost' 7 - 18-ročnej mládeže v ČSFR. (159-166). Bratislava: Šport. 